\title{
Universiteit
}

Leiden

The Netherlands

\section{Who decides the worth of an arm and a leg? Assessing the monetary value of nonmonetary damage}

Poletiek, F.H.; Stolker, C.J.J.M.; Kurz-Milcke E., Gigerenzer G.

\section{Citation}

Poletiek, F. H., \& Stolker, C. J. J. M. (2004). Who decides the worth of an arm and a leg? Assessing the monetary value of nonmonetary damage. In G. G. Kurz-Milcke E. (Ed.), Experts i Science and Society (pp. 201-213). New York: Kluwer Academic/Plenum Publishers. Retrieved from https://hdl.handle.net/1887/1953

Version: $\quad$ Not Applicable (or Unknown)

License: $\quad$ Leiden University Non-exclusive license

Downloaded from: $\quad$ https://hdl.handle.net/1887/1953

Note: To cite this publication please use the final published version (if applicable). 


\title{
Chapter 10
}

\section{Who Decides the Worth of an Arm and a Leg? Assessing the Monetary Value of Nonmonetary Damage}

\author{
Fenna H. Poletiek and Carel J. J. M. Stolker \\ Cognitive Psychology and Meijers Institute of Legal Studies, Leiden University, The Netherlands \\ poletiek@fsw.leidenuniv.nl \\ c.j.j.m.stolker@law.leidenuniv.nl
}

Nonpecuniary damage is the legal term for both some non-economic loss and the monetary compensation of this loss. The term sounds like a paradox. Indeed, it unifies, on the one hand, hard material value, and on the other, an emotion impossible to quantify: suffering. In spite of this philosophical argument, however, the paradox has to be solved in at least one practical context: the assignment of monetary compensation to victims harmed by a liable third person. The question is: How much has, and will, the victim suffer(ed) and, accordingly, how much money should they obtain to "repair" the damage? This judgment requires that grief be expressed in a monetary value. But, how can this translation of grief be made in monetary terms? Also, who is qualified to make this assessment? That is, who is taken as the expert in the present practice, and who should be considered so, in this legal procedure?

The analysis of this problem proceeds in three parts: First, we question what the legal concept of "nonpecuniary damage" is, and what the implications for making this assessment are. We will show that the assessment consists of two different aspects, which we will call subjective and objective aspects. Second, we question who is the expert, and for which aspect of the assessment? In this section, we present some data comparing the assessment by courts and laypersons on the severity of injuries. Third, we present arguments for a standardization of this assessment, and discuss the debates on such a standardization, considering, from a sociological point of view, the role and interests of the actors involved. Our study focuses on the Dutch law and the situation in the Netherlands. However, the problem of translating victims' suffering into a quantified amount of damage, to be paid by a liable party, exists in most Western societies. Consequently, our analysis may be generalized, to some extent, beyond the country's frontiers. 


\section{The Legal Philosophy of Nonpecuniary Damages}

The Article 6:106 of the New Dutch Civil Code (19921) reads:

The victim has the right to fairly determined reparation of harm other than economic damage:

a. if the person liable had the intention to inflict such non-economic harm;

b. if the victim has suffered physical injury, injury in honor or reputation, or if this person has been otherwise afflicted.

However, this text reveals a few intentions the legislature had about nonpecuniary damages. Although nonpecuniary damages can be awarded in a large number of cases (mentioned above under b.), we focus on the cases in which the victim has suffered physical injury. First, it is meant as reparation of harm. In other words, these damages should compensate for something that is lost. This implies that the amount of damages, somehow, should be in accordance with the amount of what is lost. Second, the damages, being reparation of harm, are not intended to punish the person liable for the harm. This clearly contrasts with the idea of "punitive damages" which exists in some common law systems. However, the damages vary as a function of the degree of liability of the wrongdoer. As the act was less intentional, the damages decrease (Dutch Civil Code, Article 6:982). A third idea behind the regulation of nonpecuniary damages in the Dutch law is that, as a principle, they cannot be assigned to relatives of a victim if the event has led to the death of the victim. Indeed, since these damages are meant to compensate the victim, allowing them to "buy new pleasure" to replace the lost one, other persons than the victim cannot, in principle, use these damages to assuage the inflicted harm (Stolker, 1990). This implication, however, is highly debated (Lindenbergh, 1998). Indeed, occasionally, the harm might not inflict the victim himself, but the relatives. This is so when the victim dies or stays in coma. In the following, we will come back to this debate. Fourth, the judge, as Article 6:106 of the Dutch Civil Code ${ }^{3}$ reads, who has to determine the amount of nonpecuniary loss, is given no more concrete instructions than that they should determine this amount in a "fair" way. But, what is fair? To answer this question, we first deal with the question of who is qualified to determine the seriousness of injuries.

${ }^{1}$ Nieuw Nederlands Burgerlijk Werboek-New Netherlands Civil Code, translation in English and French by P. P. C. Haanappel \& Ejan Mackaay, Kluwer Law and Taxation Publishers, Deventer/Boston 1990.

${ }^{2}$ See foornote 1.

3 See footnote 1 . 


\section{Who Is Expert for Assessing Nonpecuniary Damages?}

The law states that the assessment should be equitable. Moreover, in Article 6:97 of the Dutch Civil Code, ${ }^{4}$ it grants the judge the freedom to "estimate these damages when no precise calculation can be made." But, what considerations should play a role in this estimation? On the one hand, there is the suffering. The Dutch Supreme Court ruled in the famous "AIDS Judgment" (19925), a case in which a patient was infected with the HIV virus due to a medical error, that compensation of nonpecuniary damages should be related to the "kind, duration, and intensity of the pain, suffering, or loss of joy in life." This judgment again reflects the concept that nonpecuniary damages aim at compensating for personal suffering. On the other hand, the legal practice is that courts base the assessment of the damages on the kind and intensity of the injury, rather than on the actual pain experienced by the individual victim, which can be two completely different assessments, as we will see below. To assess the "intensity" of an injury, courts apply a list of injuries, categorized with regard to their seriousness, in categories varying from mild to extremely severe.

This "list" is constructed on the basis of case law; a compilation of hundreds of judgments on nonpecuniary damages from all Dutch courts, the so-called ANWB list (composed by the Dutch Motorists Association [ANWB]). In turn, this database of past amounts assigned has become the informal standard to courts for determining damages in future cases. How did this "list" derive? Before the "list" existed, courts decided in each case on the basis of their estimation of the victim's suffering. From 1957 onward, decisions on nonpecuniary damages were systematically registered by the ANWB and, importantly, categorized and ranked according to injury. The result is a hierarchy of groups of injuries and corresponding monetary amounts, reflecting the average damages assigned in cases in which a particular injury was suffered. In sum, the seriousness of injuries, as estimated and inferred from past judgments, now predominantly determines the practice of the assessment of nonpecuniary damages by courts, rather than individual suffering aspects.

Interestingly, those two factors (personal suffering and injury) can conflict. Indeed, focusing on the intensity of pain implies that the subjective individual experience is taken as the ground for the "loss" that should be compensated. We, therefore, will call the victim-related factor the "subjective aspect." By contrast, taking the injury as the standard implies that the objective observable result of the event is to be compensated. Accordingly, the injury-related aspect will be called the "objective aspect." Consider, as an example, two victims from different accidents, resulting with the same injury: an amputated leg. According to the courts' actual practice, in which the injury is taken as the relevant factor, those two people should obtain the same amount of damages. The subjectively felt pain, however, may vary greatly between victims, depending on the unique indi-

${ }^{4}$ See footnote 1.

5 HR 8 July 1992, Nederlandse Jurisprudentie 1992, 714. 


\section{The Legal Philosophy of Nonpecuniary Damages}

The Article 6:106 of the New Dutch Civil Code (19921) reads:

The victim has the right to fairly determined reparation of harm other than economic damage:

a. if the person liable had the intention to inflict such non-economic harm;

b. if the victim has suffered physical injury, injury in honor or reputation, or if this person has been otherwise afflicted.

However, this text reveals a few intentions the legislature had about nonpecuniary damages. Although nonpecuniary damages can be awarded in a large number of cases (mentioned above under b.), we focus on the cases in which the victim has suffered physical injury. First, it is meant as reparation of harm. In other words, these damages should compensate for something that is lost. This implies that the amount of damages, somehow, should be in accordance with the amount of what is lost. Second, the damages, being reparation of harm, are not intended to punish the person liable for the harm. This clearly contrasts with the idea of "punitive damages" which exists in some common law systems. However, the damages vary as a function of the degree of liability of the wrongdoer. As the act was less intentional, the damages decrease (Dutch Civil Code, Article 6:982). A third idea behind the regulation of nonpecuniary damages in the Dutch law is that, as a principle, they cannot be assigned to relatives of a victim if the event has led to the death of the victim. Indeed, since these damages are meant to compensate the victim, allowing them to "buy new pleasure" to replace the lost one, other persons than the victim cannot, in principle, use these damages to assuage the inflicted harm (Stolker, 1990). This implication, however, is highly debated (Lindenbergh, 1998). Indeed, occasionally, the harm might not inflict the victim himself, but the relatives. This is so when the victim dies or stays in coma. In the following, we will come back to this debate. Fourth, the judge, as Article 6:106 of the Dutch Civil Code ${ }^{3}$ reads, who has to determine the amount of nonpecuniary loss, is given no more concrete instructions than that they should determine this amount in a "fair" way. But, what is fair? To answer this question, we first deal with the question of who is qualified to determine the seriousness of injuries.

${ }^{1}$ Nieuw Nederlands Burgerlijk Wetboek-New Netherlands Civil Code, translation in English and French by P. P. C. Haanappel \& Ejan Mackaay, Kluwer Law and Taxation Publishers, Deventer/Boston 1990.

${ }^{2}$ See footnore 1 .

${ }^{3}$ See footnote 1 . 


\section{Who is Expert for Assessing Nonpecuniary Damages?}

The law states that the assessment should be equitable. Moreover, in Article 6:97 of the Dutch Civil Code, ${ }^{4}$ it grants the judge the freedom to "estimate these damages when no precise calculation can be made." But, what considerations should play a role in this estimation? On the one hand, there is the suffering. The Dutch Supreme Court ruled in the famous "AIDS Judgment" $\left(1992^{5}\right)$, a case in which a patient was infected with the HIV virus due to a medical error, that compensation of nonpecuniary damages should be related to the "kind, duration, and intensity of the pain, suffering, or loss of joy in life." This judgment again reflects the concept that nonpecuniary damages aim at compensating for personal suffering. On the other hand, the legal practice is that courts base the assessment of the damages on the kind and intensity of the injury, rather than on the actual pain experienced by the individual victim, which can be two completely different assessments, as we will see below. To assess the "intensity" of an injury, courts apply a list of injuries, categorized with regard to their seriousness, in categories varying from mild to extremely severe.

This "list" is constructed on the basis of case law; a compilation of hundreds of judgments on nonpecuniary damages from all Dutch courts, the so-called ANWB list (composed by the Dutch Motorists Association [ANWB]). In turn, this database of past amounts asşigned has become the informal standard to courts for determining damages in future cases. How did this "list" derive? Before the "list" existed, courts decided in each case on the basis of their estimation of the victim's suffering. From 1957 onward, decisions on nonpecuniary damages were systematically registered by the ANWB and, importantly, categorized and ranked according to injury. The result is a hierarchy of groups of injuries and corresponding monetary amounts, reflecting the average damages assigned in cases in which a particular injury was suffered. In sum, the seriousness of injuries, as estimated and inferred from past judgments, now predominantly determines the practice of the assessment of nonpecuniary damages by courts, rather than individual suffering aspects.

Interestingly, those two factors (personal suffering and injury) can conflict. Indeed, focusing on the intensity of pain implies that the subjective individual experience is taken as the ground for the "loss" that should be compensated. We, therefore, will call the victim-related factor the "subjective aspect." By contrast, taking the injury as the standard implies that the objective observable result of the event is to be compensated. Accordingly, the injury-related aspect will be called the "objective aspect." Consider, as an example, two victims from different accidents, resulting with the same injury: an amputated leg. According to the courts' actual practice, in which the injury is taken as the relevant factor, those two people should obtain the same amount of damages. The subjectively felt pain, however, may vary greatly between victims, depending on the unique indi-

\footnotetext{
${ }^{4}$ See footnote 1 .

${ }^{5}$ HR 8 July 1992, Nederlandse Jurisprudentie 1992, 714.
} 
vidual and the event. This uniqueness can derive from numerous circumstances, for example, relating to personal characteristics, such as age, sex, and profession, but also from the attitude of the actor regarding the event. The implication of this is that if their suffering is different, the amount of damages should be, too. Summarizing, the objective factor satisfies the fairness principle in justice that people with the same injury should be compensated equally. The subjective factor satisfies the adequacy principle that the damages should reflect, adequately, the actual amount of subjective lost joy.

How do courts come to terms with this contradiction? In the argumentation preceding the final decision on the damages in court or in settlement, the subjective aspects of the suffering are often highly emphasized, especially by the victims' lawyers. Particular individual circumstances and feelings are argued to interact and add up to the injury itself, increasing the victim's suffering. However, research has shown that judges do nor allow their judgments to be influenced much by these arguments. They generally adhere to the "list." It has been shown in a statistical analysis of court decisions (Ferwerda, 1987; Vollbehr, 1989) that the final decision on the amount of damages is hardly influenced by subjective circumstances of the victim. The objective factor "seriousness of the injury" almost fully determines the variance of the judgments.

The fact that the estimations of damages by courts barely take into account subjective particularities of the suffering may have two reasons: First, some of these circumstances are very difficult to assess because they require the valuation of some very personal feelings. Second, what are the reasonable subjective circumstances to take into account? In the literature, many factors have been advanced (Stolker \& Poletiek, 1998), among which are income and social position of the victim. But, authors disagree as to which individual characreristics are relevant for assessing the damages (Lindenbergh, 1998). The third reason may be that courts just do not know how these characteristics should affect their judgment. For example, is a high income a reason for increasing or rather lowering the damages? Should it be assumed that rich persons suffer less or more than poor persons?

The objective factor, the severity of the injury, has to be assessed in a different way than the subjective factor. The injury itself can often be determined by a diagnosis from a medical expert. However, the problem is to determine its "intensity" (seriousness) compared to other injuries. Vollbehr (1989), Pieters and van Busschbach (1989), and Stolker and Poletiek (1998) point at the arbitrary character of the "seriousness categorization" of the injuries on the ANWB list. This database reflects what courts consider about the seriousness of injuries, both relatively (one injury as compared to the others) and absolutely (each injury is supposed to correspond to a certain amount of loss in the joy of life, monetarily expressed). This raises the question as to who is the expert in assessing the relative and absolute severity of health damages. We consider three possibilities: first, the court. This is the point of view taken implicitly by our legal system, because this is the practice. The courts base their decisions on the "list," which in turn is a compilation of court judgments. However, apart from making an accurate esti- 
mation of the damages, courts might have other concerns. For example, courts may tend to keep the seriousness low in order to avoid case laws with huge monetary amounts on the basis of which new victims might base new claims. Also, their estimations on the seriousness of injuries might be affected by factors, such as social status, which is generally above average for judges. Notice, that these considerations only apply to non-jury systems. Second, the victims themselves might be considered as the expert in determining how serious the injury is, absolutely as well as relatively, in comparison to other injuries. However, the victims are influenced by other subjective factors, which might bias their estimation. For example, the very fact that the victims can claim monetary compensation might bias their perception of the seriousness of the injury. The third possible expert is the possible victim, being the civilian to whom this legislation applies. We believe that they are the experts on whose judgment the estimation of the seriousness of injuries should be based, in order to be most in accordance with the legislation. Indeed, possible victims are expected to be least prone to maximize or minimize the estimated seriousness of injuries, for strategic reasons. Thus, the standard on which the court bases its estimation of seriousness of injuries should reflect the feelings of "the person on the street" (being the possible victim) about relative and absolute seriousness of injuries.

In the study we present below, we further investigated this point of view by comparing the courts' (ANWB list) and civilians' estimations on the seriousness of their injuries. Such a test of the "list" has never been performed, although differences in the estimations courts and people use might have serious financial implications for victims, depending on whose expertise is used as a basis.

\section{Comparing the Courts' Estimations With Laypersons'}

\section{Estimations}

The problem of the assessment of the seriousness of injuries can be formulated in psychological terms, such as how to measure utilities of health states. In the field of medical decision making, this is an elaborate research program. Indeed, cost effectiveness analyses of medical interventions require that the patients' experienced health states be quantified, in order to compare the costs of interventions with their benefits in terms of experienced quality of life (Bakker \& van der Linden, 1995).

The methods applied to measure utilities of health states can also be used in the context of the legal assessment of nonpecuniary damages. We will first investigate the relative utilities of injuries (ranking) by laypersons, which can be directly compared with the courts' standard. Next, we estimate the absolute utilities of the injuries. These utilities can be compared with the actual average amounts of nonpecuniary damages assigned by courts in the past, as they figure in the standard "list." We also measured the utilities of a number of events for which no nonpecuniary damages can legally be claimed. These are the cases in 
which a relative (e.g., child, partner) has died due to some event for which a third person is liable (Article 6:108 of the Dutch Civil Code ${ }^{6}$ ) and cases in which the victim is in permanent coma. The latter cases are not explicitly excluded from the right of nonpecuniary damages by the law, but they are generally interpreted to be so by legal experts (Stolker, 1990). Since these cases (death of relative, permanent coma of victim) are the topic of a lively public discussion, we investigated them in our study.

\section{The Ranking of Injuries}

Ninety-one persons participated in this study on a voluntary basis. The participants completed a questionnaire with 19 descriptions of injuries. The injuries were a selection of those mentioned in the ANWB list, plus 3. These are "the death of one's child," the "death of one's partner," and "being in permanent coma." Participants were requested to rate the impact these injuries would have on their quality of life, on a scale varying from 0 (no influence on my quality of

\section{Table 1}

Ranking of Injuries According to Seriousness by Participants $(N=91)$

\begin{tabular}{lc}
\hline & Thurstone score \\
\hline Broken teeth & 1.58 \\
Amputation of fingertip & 1.27 \\
Lost sense of smell & 0.69 \\
Lost sense of taste & 0.67 \\
Large scar on the face & 0.46 \\
One-sided deafness & 0.45 \\
Light whiplash & 0.44 \\
Forgetfulness/concentration problems & 0.05 \\
Change of character; irritability & -0.04 \\
Depression & -0.12 \\
Amputation of one arm & -0.40 \\
Mutilation of the face & -0.45 \\
Severe whiplash & -0.47 \\
Amputation of one leg & -0.81 \\
*Death of a partner & -0.86 \\
Incapacity of (non)verbal communication & -0.88 \\
*Death of own child & -0.94 \\
Paralysis of both legs & -1.03 \\
*Permanent coma & -1.28 \\
\hline
\end{tabular}

* Injuries that are not liable for compensation under the present Dutch law on nonpecuniary damages.

${ }^{6}$ See footnote 1. 
life) to 9 (my quality of life would be as much affected as by death). The rating scores were analyzed by means of the Thurstone Method. With this method, not only the ranking of the injuries of all participants can be calculated, but also the "distances" between the injuries on the criterion "influence on quality of life" can be inferred. This is obtained by calculating a z-score for each injury. This z-score becomes negative when severe, and positive when not. In Table 1, the ranking of the injuries by participants and the corresponding Thurstone Scores are displayed.

The standard "list" is represented as a ranking with discrete categories. The injuries belonging to one category share the same position in the ranking. The ranking globally matches the courts' ranking. There are some differences, however. In order to compare the continuous participants' ranking with the courts' categorization, a difference between the two "lists" was defined as significant when two injuries, ranked in a certain order by participants, were inversely assigned to two courts' categories. First, participants rate loss of taste to be less severe than a severe whiplash, the courts hold the reverse. Another difference exists with regard to a "scar in the face." According to the courts, this should cause less suffering than the amputation of the middle finger. However, according to the participants, the inverse is true. With regard to loss of taste and smell, there is also disagreement between the courts and the respondents. These two injuries are estimated as less painful than a large scar on the face, a light or severe whiplash, and one-sided deafness, whereas the courts put loss of taste or smell in a more severe category than these. Finally, it can be seen that the three events not "repairable" by damages according to the law, are considered most serious by laypeople, placing them at the bottom of the ranking in Table 2. Loosing one's partner, one's child, and being in permanent coma are felt as the most painful events that can happen.

How can these differences be explained? We suggest some tentative explanations. First, whiplashes can affect victims in many ways. They can cause various somatic as well as psychological effects, which are difficult to diagnose. In addition, this injury has obtained much attention from the media, precisely because of its poorly explained and sometimes dramatic effects on victims. Courts might estimate the impact of such "soft" injuries lower than people do. Inversely, loss of taste or smell are injuries that are possibly not well imaginable by people because they are not very frequent, and, therefore, are estimated low. Courts, however, have been faced more frequently with these injuries and estimate their seriousness higher on the basis of life reports from victims. Scars that are visible do not affect one's physical health, but possibly one's identity and self-image. Apparently, such an injury is more important for people than courts believe. The same argument might apply to whiplashes: Courts might think of these psychological effects as fuzzy and, therefore, underestimate their seriousness. With regard to the ratings of the events, which are not compensable by damages, we return to them below.

Apart from the ranking of injuries, we compared the absolute monetary amounts associated to these injuries by both groups. For this, we used the "Willingness-to-Pay" (WTP) Method. With this method, the psychological value of a 
"good" or a "loss" can be measured. It is frequently used in medical decision making for measuring the utilities of health states (O'Brien \& Viramontes, 1994). It proceeds as follows: People are asked how much they would be willing to pay to be entirely cured from injury or illness. Their answer expresses the estimated amount of suffering in monetary terms. In the present study, we asked the respondents to give their WTP value for two injuries only: the one they rated as the least severe and the one they rated as the most severe. The mean least severe WTP score and the mean most severe WTP score were taken as the extreme values of the utilities accorded to the average least and most severe injuries. The WTP amounts for the remaining injuries were obtained by interpolation. The intervals between the injuries were calculated on the basis of the Thurstone scores obtained in the ranking. Thus, the distances between the injuries, calculated with the Thurstone scores, were reflected in the estimated WTP scores. These scores are displayed in Table 2, together with the mean damages awarded by the courts for each category of injuries. The amounts in Dutch guilders, were converted to Euro.

Table 2

WTP Values of Injuries $(N=91)$ and Average Damages Awarded by Courts (in Euro)

\begin{tabular}{|c|c|c|c|}
\hline $\begin{array}{l}\text { Injury categories accord- } \\
\text { ing to standard "list"" }\end{array}$ & Injuries & $\begin{array}{l}\text { Average amounts assigned } \\
\text { damages by courts }\end{array}$ & $\begin{array}{l}\text { WTP } \\
\text { Values }\end{array}$ \\
\hline Mild & $\begin{array}{l}\text { Broken teeth } \\
\text { Large scar on face }\end{array}$ & $1,364-2,500$ & $\begin{array}{r}2,672 \\
46,228\end{array}$ \\
\hline Very light & $\begin{array}{l}\text { Light whiplash } \\
\text { Amputation of fingertip }\end{array}$ & $2,500-6,818$ & $\begin{array}{l}47,006 \\
14,727\end{array}$ \\
\hline Light & $\begin{array}{l}\text { One-sided deafness } \\
\text { Severe whiplash }\end{array}$ & $6,818-13,636$ & $\begin{array}{l}46,617 \\
82,396\end{array}$ \\
\hline Serious & $\begin{array}{l}\text { Lost sense of taste } \\
\text { Lost sense of smell } \\
\text { Forgetfulness } \\
\text { Change of character }\end{array}$ & $13,636-25,000$ & $\begin{array}{l}38,061 \\
37,284 \\
62,214 \\
65,673\end{array}$ \\
\hline Very serious & $\begin{array}{l}\text { Depression } \\
\text { Amputation of one arm } \\
\text { Amputation of one leg } \\
\text { Paralysis of both legs }\end{array}$ & $25,000-50,000$ & $\begin{array}{r}68,785 \\
79,674 \\
95,618 \\
104,174\end{array}$ \\
\hline Extremely serious & $\begin{array}{l}\text { Mutilation of face } \\
\text { Communication problem } \\
\text { *Death of a partner } \\
\text { *Death of own child } \\
\text { *Permanent coma }\end{array}$ & $>50,000$ & $\begin{array}{r}81,618 \\
98,340 \\
97,363 \\
100,674 \\
113,897\end{array}$ \\
\hline
\end{tabular}

* Injuries that are not liable for compensation under the present Dutch law on nonpecuniary damages. 
As can be seen in Table 2, the average WTP scores resulting from this interpolation are higher than the damages. The differences between the two "lists" indicate that courts associate less compensation with the injuries than civilians would estimate to be necessary, given their seriousness. The differences especially increase when the injuries are more severe. In the highest category, courts assign an amount of 50.000 Euro or higher. However, this amount is only about half the amount people assign on average to the most severe injuries.

A few remarks must be made with regard to the WTP Method. First, the responses are sensitive to income position. Indeed, people with a higher income position may be willing (because capable) to spend more money for cure than people with a lower income position, for the same suffering. In our sample, different income positions are represented, and the WTP scores are averaged. Therefore, we chose to report the raw WTP scores. A second problem is that quite a few participants (40) gave no specific amount as a response, but answered "millions" or "everything I have" when asked to rate the "most severe injury or event." Those responses were excluded from the calculations in Table 2. We return to this in the next section.

The main conclusions from the present comparison of courts' with laypeople's opinions on injuries are firstly that both rankings and absolute estimations of the seriousness of injuries differ on a number of items. Thus, considering civilian rather than courts as the experts makes a difference. The values of the severity of injuries expressed monetarily are, on average, almost twice as high as the average damages from courts. Second, events not compensable by damages, such as the loss of a partner or a child and being in a permanent coma, belong to the most painful experiences people can imagine: They correspond to what people conceive as the greatest loss of quality of life. This reveals the most striking incompatibility between the court's attitude, on the one hand, and layperson's attitude, on the other, toward the seriousness of injuries. We discuss this difference more in detail below.

Although courts do not even consider compensation for pain caused by damages to relatives, this pain is the most severe people can imagine. The law text on nonpecuniary damages assumes that the victim of the event, for which a third person is legally liable, is the one that should be compensated for the pain felt, so that they can "buy" back the lost joy of life. Since a dead person cannot benefit in such a manner from compensation, those victims are excluded from the right to damages, as follows in Article 6:108 of the Dutch Civil Code. ${ }^{7}$ In the same line of argument, it has been proposed that people in permanent coma (or their relatives) should not be compensated either (Stolker, 1990). However, our study shows that the suffering caused to a relative by the death or coma of their partner or child, is one of the most severe ones. The suffering being so intense, it seems reasonable to compensate it somehow. Another argument in favor of damages for surviving relatives is the Supreme Court's AIDS judgment ${ }^{8}$ on nonpecuniary

\footnotetext{
7 See footnote 1.

${ }^{8}$ See footnote 5 .
} 
damages. It rules that the suffering, its intensity, and duration are the entities to be compensated. In this statement, the court emphasizes that the suffering, rather than the victim as a person, should be indemnified. In sum, in line with the adequacy principle, according to which the amount of pain inflicted is what should be compensated, it is arguable that relatives, if they suffer the pain ensuing from the event having caused the dearh or coma of the victim, should be entitled to obtain some damages. This is in contrast with the adequacy principle underlying the law.

Recently, however, in a so-called "nervous shock case," the Dutch Supreme Court authorized the recovery of both pecuniary and nonpecuniary damages by a close relative of a victim of a tort in certain siruations. ${ }^{9}$ The claimant relative must either observe the tort or be confronted immediately thereafter with the suffering or death of the close relative. In addition, a serious mental injury (the court uses the words "recognized psychiarric damage") on the part of the observer claimant is a prerequisite and, therefore, the courr in the case dismissed the claim as far as "only" affective damage (bereavement damages-misery, grief, sorrow) was concerned. Compensating mere affective damage would, indeed, be in conflict with the general principle underlying the law on nonpecuniary damages (Levine \& Stolker, 2001).

A final remark must be made with regard to these cases. We observed that it was particularly difficult for people to quantify suffering when the suffering was extremely severe. This was expressed in the answers to the WTP question with regard to the death of a partner or child. To our surprise, many respondents gave unlimited answers, such as: "everything I have." Damages are more difficult to express monetarily as the loss of joy of life is more extreme. Allowing for compensation in these cases again raises the problem: How much should this be? The full discussion of this problem is beyond the scope of this study. But, a possible solution might be to fix a symbolic amount for these cases, meeting the need for some recognition of the inflicted pain without trying to fully compensate it materially.

\section{Standardized Assessment: What Are the Advantages and for Whom?}

Resuming the previous arguments and findings, we propose that the assessment of nonpecuniary damages is the combination of two aspects. First, an objective aspect on the severity of the injury and, second, a subjective aspect which is the actual individual suffering. These aspects are to be assessed and combined, resulting in an amount of compensation. Although this assessment has, in the past, been fully assigned to the competence of the courts, we have argued that the assessment of the objective part should be based on the opinion of civilians.

${ }^{9}$ Hoge Raad 22 February 2002, Rechtspraak van de Week 2002, 48. 
We showed that transferring this expert role from the court to the civilians makes a reasonable difference.

The present perspective on the assessment of nonpecuniary damages and the expertise question, furthermore, raises the question as to how this judgment process might be carried out in practice. The two contrasting answers to this question are, first, a standardized procedure and, second, individual judgments of each case. The second method is the current practice in the Netherlands. The severity of the injury, as well as the individual suffering, are weighted and estimated in each individual case by the court and combined to one final monetary amount. Interestingly, in the past, a few attempts were carried out to allow the assessment of nonpecuniary damages to be defined by some kind of standardized procedure. For example, in 1984, the Dutch Association of Insurers proposed a "formula" for calculating the damages. It is a very simple algorithm calculating the damages on the basis of the duration of therapy and recovery, the extent to which the person is disabled (which are rather injury-related "objective" factors, as we called them), and the victim's age (which is victim-related and, therefore, subjective). All these factors were quite easy to assess and were actually assessed by the court. The formula, however, has hardly been applied in practice. The algorithm was considered to be too simple and the amounts it generated too low and quite arbitrary. In sum, it was seen as equally arbitrary as just using the "list."

However, surprisingly, the criticism that this standardized procedure received was not directed at the parameters of the formula, but primarily at the very fact of standardizing the assessment. The criticism came from legal experts, especially lawyers, attacking the procedure on the grounds of prohibiting proper allowance for numerous subjective circumstances of the individual victim. In fact, it is in the lawyer's interest to leave some untransparency regarding the damages. This allows the lawyers, within the margins of this opacity, to plead for maximization of the damages, on the basis of the unique situation and characteristics of their client and the situation. Insurers, however, are interested in predictability. Indeed, they are almost always the party who actually awards the compensation. In order to calculate their premiums, they are required to perform accurate cost predictions. This is obviously more simplified when the parameters of the decision procedure are known, bearing in mind that it was the insurers who first proposed the "formula."

Finally, what are the consequences of standardization for the victims? The law exists as a regulation for the victims' right to fair compensation. On the one hand, victims, as a group, benefit from a transparent standardized procedure, where standardization increases fairness. On the other hand, it has been suggested that this procedure can also be applied against the individual interests of victims. Their unique circumstances are, then, presumably dismissed. However, there are also a few arguments in favor of a standardized approach for the individual. Firstly, as we mentioned above, courts in practice seldom take into account subjective factors, but base their judgment mainly on the severity of the injury, apparently in spite of the subject-based pleas from lawyers. Thus, a stan- 
dardized procedure, in which a fixed weight would be given to objective and subjective factors, might provide an improved, rather than a detrimental guarantee that subjective aspects affecting the experienced pain are taken into account. Secondly, however, subjective circumstances can also be applied against the individuals' interest. Consider a right-handed illustrator having their left-hand paralyzed. Since this injury does not impede their professional work, the damages might be lowered precisely due to their unique characteristics. In a procedure as the one sketched above, the individual and subjectively felt pain, on the one hand, and the objective severity of the injury, on the other, can be balanced similarly for all victims, allowing acceptable subjective elements to perform a role. Another advantage of leaving the assessment of emotional damages to an "expert procedure" is that it is intelligible and transparent to individuals, increasing its acceptability (van den Bos, Lind, \& Wilke, 2001).

In conclusion, standardizing the assessment of nonpecuniary damages might be a reasonable way to translate suffering into monetary compensation. In such a procedure the relative weight of the objective and subjective assessment, can be calculated. However, expert roles should be adequately attributed, as we argued. Expertise for estimating the subjective factors should be provided by the victim, and expertise for estimating the severity of the injury should be produced by the possible victims, who actually are all civilian concerned by the legal system. In our view, such a model allows for the difficult task of assessing nonpecuniary damages to be performed in accordance with the intentions of the legislation.

\section{Authors' Note}

We thank Mark van Oostrum, Richard Tijink and Willem van der Kloot for their assistance in carrying out the empirical study and analyzing the data.

\section{References}

Bakker, C., \& van der Linden, S. (1995). Health related utility measurement: An introduction. The Journal of Rheumatology. 22, 1197-1199.

Ferwerda, M. P. (1987). Statistische analyse van smartegelduitspraken [Statistical analysis of nonpecuniary damages judgments]. Verkeersrecht, 5, 122-124.

Levine, D. I., \& Stolker, C. J. J. M. (2001). Compensating for psychiatric damage after disasters: A plea for a multifactor approach. In E. R. Muller \& C. J. J. M. Stolker (Eds.), Ramp en recht (pp. 127-148). The Hague: Boom Juridische Uitgevers.

Lindenbergh, S. D. (1998). Smartengeld [Nonpecuniary damages]. Deventer, The Netherlands: Kluwer.

Stolker, C. J. J. M. (1990). The unconscious plaintiff: Consciousness as a prerequisite for compensation of non-pecuniary loss. The International and Comparative Law Quarterly, 39, 82-100.

Stolker, C. J. J. M., \& Poletiek, F. H. (1998). Smartengeld-Wat zijn we eigenlijk aan het doen? Naar een juridische en psychologische evaluatie [Toward a legal and psychological evaluation of nonpecuniary damages]. In E. Stadermann et al. (Ed.), Bewijs en letselschade (pp. 71-86). Lelystad, The Netherlands: Koninklijke Vermande. 
O'Brien, B., \& Viramontes, J. L. (1994). Willingness to pay: $A$ valid and reliable measure of health state preference? Medical Decision Making, 14, 289-297.

Pieters, J. A., \& Busschbach, J. J. van. (1989). Een empirisch onderzoek naar de vaststelling van smartengeld in geval van letsel [An empirical investigation into the assessment of damages in case of injury]. Verkeersrecht, 6, 141-146.

van den Bos, K., Lind, E. A., \& Wilke, H. A. M. (2001). The psychology of procedural and distributive justice viewed from the perspective of fairness heuristic theory. In R. Cropanzano (Ed.), Justice in the workplace: From theory to practice (pp. 49-66). Mahwah, NJ: Erlbaum.

Vollbehr, W. (1989). Smartegeld en willekeur [Nonpecuniary damages and arbitrariness]. Verkeersrecht, 6, 146-150. 